\title{
Monitoring and Notification System Air Quality Against Carbon Monoxide in The Study Room IoT based
}

Sistem Monitoring dan Notifikasi Kualitas Udara Terhadap Karbon Monoksida dalam Ruangan Belajar Berbasis IoT

Received:

13 September 2020

Accepted:

20 January 2021

Published:

1 February 2021

\author{
${ }^{\text {1*} M a d e ~ A y u ~ D u s e a ~ W i d y a d a r a, ~}{ }^{2}$ Kartika Rahayu Tri Prasetyo \\ Sari \\ ${ }^{1}$ Teknik Informatika Universitas Nusantara PGRI Kediri, ${ }^{2}$ Teknik \\ Elektronika Universitas Nusantara PGRI Kediri \\ ${ }^{1,2}$ Kediri, Indonesia
}

E-mail: ${ }^{1}$ madedara@unpkediri.ac.id, ${ }^{2}$ kartika@unpkediri.ac.id

*Corresponding Author

\begin{abstract}
The increase in human activities has triggered air pollution, especially in school areas. It results from various kinds of gases from exhausts or combustion that harm health and air quality for the community. The source of air pollution from motorized vehicles is one of the most significant contributors to air pollution in the school area. To prevent and control air pollution, a tool is needed to measure the gas levels. In this study, the tool used has a feature of monitoring air quality with the Internet of Things (IoT) platform. An essential part of this device is a sensor based on a microcontroller, where The device will send the data obtained by the MQ135 sensor module to the IoT platform. People can access information about air quality via smartphone devices for air quality information in the study room. This study's average result in detecting air quality is 495 , indicating a moderate level of air pollution. With the existence of an air quality monitoring and notification system in this study room, it has the potential for awareness about the importance of healthy air quality for the community, especially students who will become the nation's next-generation students 8 hours learning environment.
\end{abstract}

Keyword-Internet Of Things, Gas, Carbon Monoxide, Monitoring, Pollution

\begin{abstract}
Abstrak - Seiring meningkatnya aktivitas manusia maka meningkat pula masalah pencemaran udara terutama pada kawasan sekolah, hal ini akibat dari berbagai macam gas yang berasal dari pembuangan atau pembakaran sehingga memberikan dampak buruk bagi kesehatan serta kualitas udara bagi masyarakat. Dalam upaya pencegahan dan mengendalikan pencemaran udara yang mengandung karbon monoksida dibutuhkan alat untuk mengukur kadar gas tersebut. Pada penelitian ini alat yang digunakan memiliki fitur memantau kualitas udara dengan platform Internet Of Things (IoT). Bagian penting dari perangkat ini adalah sensor yang berbasis mikrokontroler, dimana data yang didapatkan oleh modul sensor MQ135 tersebut akan dikirimkan ke platform IoT. Sehingga informasi mengenai kualitas udara dalam ruang belajar yang dapat diakses melalui perangkat telepon pintar untuk informasi tentang kualitas udara pada ruang belajar tersebut kepada pengguna. Hasil rata-rata pada penelitian ini dalam mendeteksi kualitas udara adalah 495 yang artinya terindikasi tingkat polusi udara menengah. Dengan adanya sistem monitoring dan notifikasi kualitas udara pada ruang belajar ini diharapkan dapat meningkatkan kesadaran tentang pentingnya kualitas udara yang sehat bagi masyarakat khususnya para siswa yang kelak menjadi generasi penerus bangsa dimana siswa memiliki waktu paling sedikit 8 jam pada lingkungan belajar.
\end{abstract}

Kata Kunci-Internet Of Things, Gas, Karbon Monoksida, Monitoring, Pencemaran 
INTENSIF, Vol.5 No.1 February 2021

ISSN: 2580-409X (Print) / 2549-6824 (Online)

DOI: https://doi.org/10.29407/intensif.v5i1.14844

\section{INTRODUCTION}

The children's study room's air condition plays a vital role in supporting children's health and learning quality. Children have approximately 8 hours in the study room and breathe the air in the study room so that the air conditioner in the study room positively affects the child's health.

Table 1. EFFECTS OF EXPOSURE TO CARBON MONOXIDE IN VARIOUS CONCENTRATIONS

\begin{tabular}{lll}
\hline \hline PPM & \multicolumn{1}{c}{ Time } & \multicolumn{1}{c}{ Information } \\
\hline $35-50$ & 8 hours & $\begin{array}{l}\text { The maximum concentration permitted for continuous exposure for } \\
8 \text { hours according to OSHA }\end{array}$ \\
\hline 200 & $2-3$ hours & Headache \\
\hline 400 & $1-2$ hours & Headache \\
\hline 800 & $\begin{array}{l}10-15 \\
\text { minutes }\end{array}$ & Dizziness, vomiting \\
\hline 1600 & 20 minutes & Headache, dizziness, death within 1 hour \\
\hline 3200 & $5-10$ minutes & Headache, dizziness, death within 1 hour \\
\hline 6400 & $1-2$ minutes & Headache, dizziness, death within 1 hour \\
\hline $6000-8000$ & 5 minutes & Incapacitation \\
\hline 12800 & $2-3$ sniff & Unconscious \\
\hline 12800 & $1-3$ minutes & Death \\
\hline source: http://www.hutchinsonutilities.com/pdf/coexposure.pdf
\end{tabular}

According to [1] PP No. 41 of 1999, the maximum limit of carbon monoxide in the air is 30 ppm in 1 hour exposure time and ten ppm in 24 hour exposure time. Humans are indeed equipped with senses that can predict if the air in the surrounding environment is considered healthy or has good air quality. But this cannot be done by humans continuously in monitoring air quality. The commercial $\mathrm{CO}$ sensors widely circulating in the market are offline notifications, so they cannot understand the current air quality level. There is only an alarm that gives a notice when the air quality level is at the dangerous limit. In this study, to monitor realtime air conditions and accurate data will be obtained about air quality in the study room. A hardware device with sensors connected to the IoT platform, is developed to monitor air quality, accessed via a smartphone where the sensor can determine air quality. However, the condition of air pollution is still below the dangerous level. It is hoped that the system that will be implemented running via a smartphone is expected to be used by everyone because smartphones are almost owned by most people than desktop applications, which can only be operated using a computer or laptop.

Several previous studies become the author's reference in conducting research and enrich the theory used in reviewing the research conducted. The study used as a reference is stated about the air quality in the library room where the air quality is affected by dust [2]. The next reference discusses $\mathrm{CO}$ gas levels in open spaces, with primary data in this reference study obtained from observation and ambient air $\mathrm{CO}$ levels using a digital $\mathrm{CO}$ analyzer (electrochemical method).[3]. 
Other research is related to the air quality detector prototype, which explains that the air quality monitoring system is carried out online by presenting the results of indoor or outdoor air quality information using the internet. [4]. Research that is still a reference material for this research describes a prototype model for monitoring air quality using a GSM module to transmit the data. [5]. Research shows a system where the system can monitor indoor air quality [6]. Research also becomes a reference where the study produces a prototype in an air quality detector that uses sensors and microcontrollers. The prototype provides a notification that can be seen via an alarm. The alarm describes the indoor air quality that has been detected by the sensor. [7]. References to subsequent research conducted by Anwari provided an understanding of the importance of knowing air quality. The study developed an existing middleware system to monitor carbon monoxide levels in the room. The data obtained from the MQ-7 sensor will be forwarded to the middleware. The middleware's data center will process the data before the end device receives the user's data [8].

Furthermore, research conducted by conducting research utilizes the Internet of Things to monitor air quality. In this study, air quality level detection was used to detect crowds [9]. Research also becomes a reference in this study where the analysis produces a prototype that detects air quality by utilizing sensors and microcontrollers. The prototype can send notifications via alarm to show the quality of air in the room. Next reference [10], namely, the MQ-7 sensor, is used as a cigarette smoke detector by sending notifications via SMS. Other research on indoor air quality is carried out in a correctional institution. Some variables affect indoor air quality, namely humidity, temperature, $\mathrm{CO}$ levels, dust, and the number of germs and fungi. This study provides suggestions for residents to maintain a clean environment where they live and better use existing air vents [11].

As a reference material, there is research on the prototype of a chicken coop temperature and humidity control system through an Android-based Blynk server, which utilizes the DHT11 sensor in measuring humidity and temperature in the monitoring system and the use of Arduino as a control system. When the DHT11 sensor captures data, Arduino will record and process the data obtained. The measurement data that has been accepted will be saved to a database displayed on the Android-based Blynk application [12]. The next reference, using the MQ-4 and MQ-135 sensors to detect harmful gases in the chicken house, where The ESP8266 will send the data obtained by the sensor, which is then displayed on the website page with a graphic display[13]. Research that still uses chicken coops has built a tool to measure air quality around the painting area at PT. Dirgantara Indonesia, this system is built using the MQ135, NodeMCU, and DHT22 sensors to determine carbon monoxide (CO2) gas[14]. 
INTENSIF, Vol.5 No.1 February 2021

ISSN: 2580-409X (Print) / 2549-6824 (Online)

DOI: https://doi.org/10.29407/intensif.v5i1.14844

The research carried out is a development of references to previous studies, wherein the end, the authors took a research topic entitled "Air Quality Monitoring and Notification Systems Against Carbon Monoxide in IoT-Based Learning Rooms." This research discusses the detection of air quality in the study room to improve health. It can also increase awareness of the importance of air quality by utilizing sensor devices with microcontrollers, where the data obtained by these sensors will be sent to the IoT platform and forwarded to applications that can be accessed by using a smartphone.

\section{RESEARCH METHOD}

The researchers chose the prototype model for this study, which has the stages in Figure 1[15]. The survey carried out initial research with a communication process (communication). This process can determine the immediate plan and objectives used to identify needs and modeling (modeling quick design) in a system design to be made. The next stage is the construction of the prototype, namely the programming and hardware assembly processes. In the next step, it is carried out after the hardware and program have been completed. It displays the system for the evaluation process (deployment delivery and feedback) carried out by prospective users to test the ease of use, completeness of the results obtained, and the system's display, which will be useful for further development.

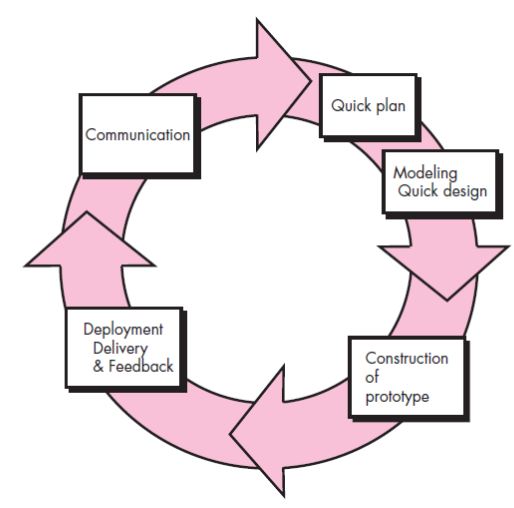

Figure 1. PROTOTYPING MODEL

In this study, researchers carried out data collection techniques using literature studies, experiments, testing tool functionality, testing air quality values, and concluding the overall results. Meanwhile, the observed variable is air quality in the study room with the carbon monoxide parameter $(\mathrm{CO})$. 
INTENSIF, Vol.5 No.1 February 2021

ISSN: 2580-409X (Print) / 2549-6824 (Online)

DOI: https://doi.org/10.29407/intensif.v5i1.14844

In this study, a system that can detect carbon monoxide (CO) levels was developed by utilizing existing event-driven IoT middleware devices. The sensor used in this study is the MQ135 sensor that is placed on each node. MQ135 is a sensitive sensor to several harmful gases, carbon monoxide (CO). In the picture below is the system design presented in Figure 2.

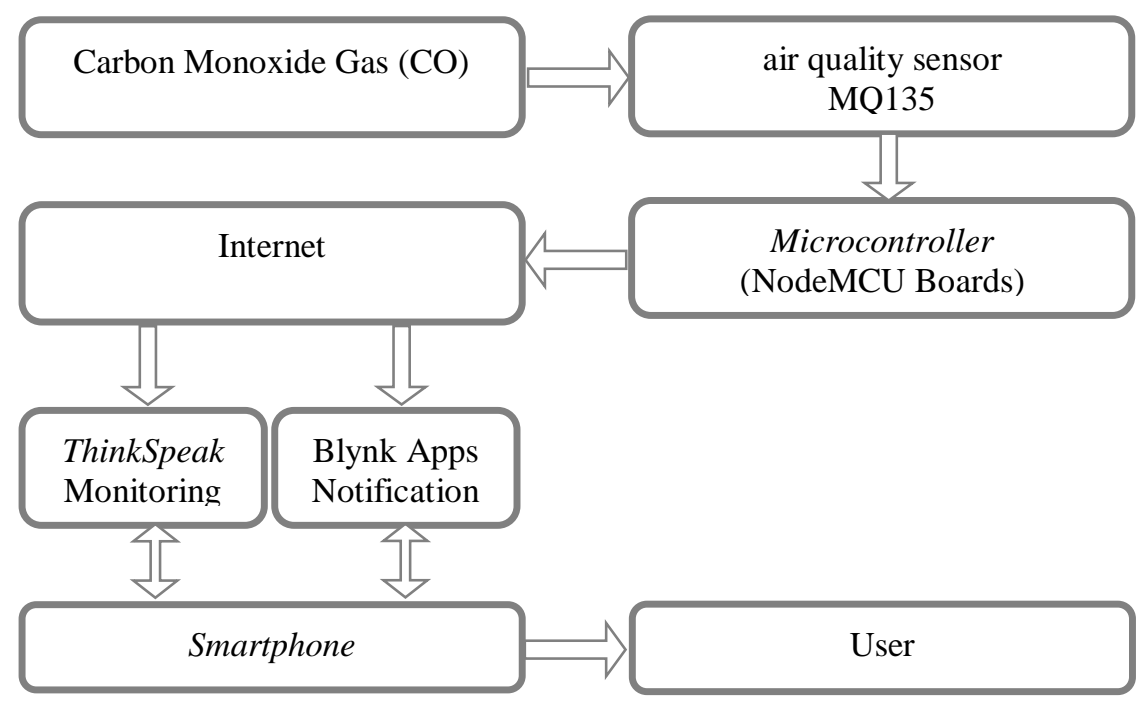

Figure 2. BLOCK DIAGRAM OF MONOXIDE CARBON DETECTION SYSTEM

In Figure 2, it describes the hardware prototype and components that have a connection to the IoT:

1. The MQ135 air quality sensor inactive condition can detect Carbon Monoxide (CO) gas.

2. The MQ135 air quality sensor is connected to the NodeMCU board device. The sensor results are sent to the NodeMCU microcontroller board, which will then be processed according to the existing program.

3. NodeMCU board, which has a wifi module, will send the detection results to the cloud.

4. The results from sensor detection are passed on to the IoT platform. Where the Blynk application is an application that functions to display air quality level notifications detected by sensors

5. Thingspeak is a platform that will provide an explanation of sensor detection results in realtime in the form of graphics [16].

6. People can access data contained in apps and Thingspeak via smartphones and computers. Information from the apps has push notifications to users when air quality is at a dangerous level. Meanwhile, Thingspeak can be accessed using a smartphone or computer, which functions as a monitoring system to record sensor detection values. By using these two platforms, users can find out real-time changes to air quality. 
INTENSIF, Vol.5 No.1 February 2021

ISSN: 2580-409X (Print) / 2549-6824 (Online)

DOI: https://doi.org/10.29407/intensif.v5i1.14844

7. Users receive air quality level notifications from apps installed on smartphones and can view air quality monitoring data by accessing thingspeak.com.

8. MQ-135 air quality sensor is a type of sensor that can be used to monitor air quality. It works by detecting the presence of ammonia gas (NH3), benzene (C6H6), sodium-dioxide (NOx), alcohol/ethanol $(\mathrm{C} 2 \mathrm{H} 5 \mathrm{OH})$, carbon monoxide $(\mathrm{CO})$, sulfur-hydroxide gas $(\mathrm{H} 2 \mathrm{~S})$, or what is called sulfur and smoke [17]. The following is the characteristic sensitivity of the MQ135 sensor to various gases.

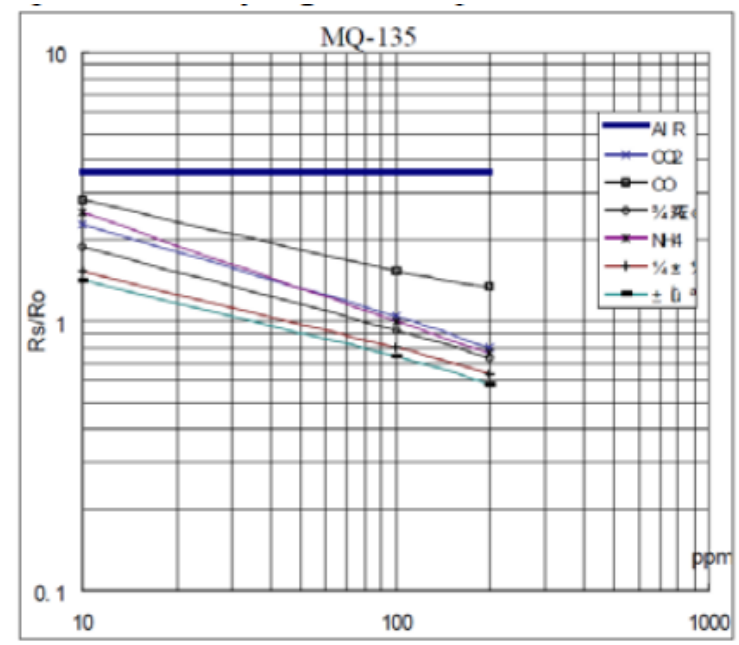

Figure 3. MQ135 SENSITIVITY CHARACTERISTICS

NodeMCU is an IoT platform that is open source and can create IoT products programmed using the Lua programming language or the Arduino IDE. [18]. This board measures $4.83 \mathrm{~cm}$ long, $2.54 \mathrm{~cm}$ wide. Despite its small size, this board is equipped with wifi features and opensource firmware, where the use of this tool uses many open source modules, such as lua-cjson and spiffs. The firmware inside functions to run the ESP8266 wifi SoC and hardware based on the ESP-12 module. [19].

Blynk is an IoS and Android-based application that can control Arduino, Raspberry Pi, and the like using the internet. Blynk is designed for IoT and can control hardware remotely, can display sensor data, store data obtained, and visualize the data [20]. Blynk apps are installed and set to be able to provide results via notifications to users. Apps Blynk can integrate with the program code on the microcontroller with a key in the Blynk id obtained when creating an account. The use of the Blynk application in this research is to display notifications via Androidbased smartphones. 
INTENSIF, Vol.5 No.1 February 2021

ISSN: 2580-409X (Print) / 2549-6824 (Online)

DOI: https://doi.org/10.29407/intensif.v5i1.14844

\section{RESULT AND DISCUSSION}

The design described previously, Figure 4 below shows that the microcontroller and sensor hardware series used to take the ppm value of carbon monoxide (CO) in the case study environment.

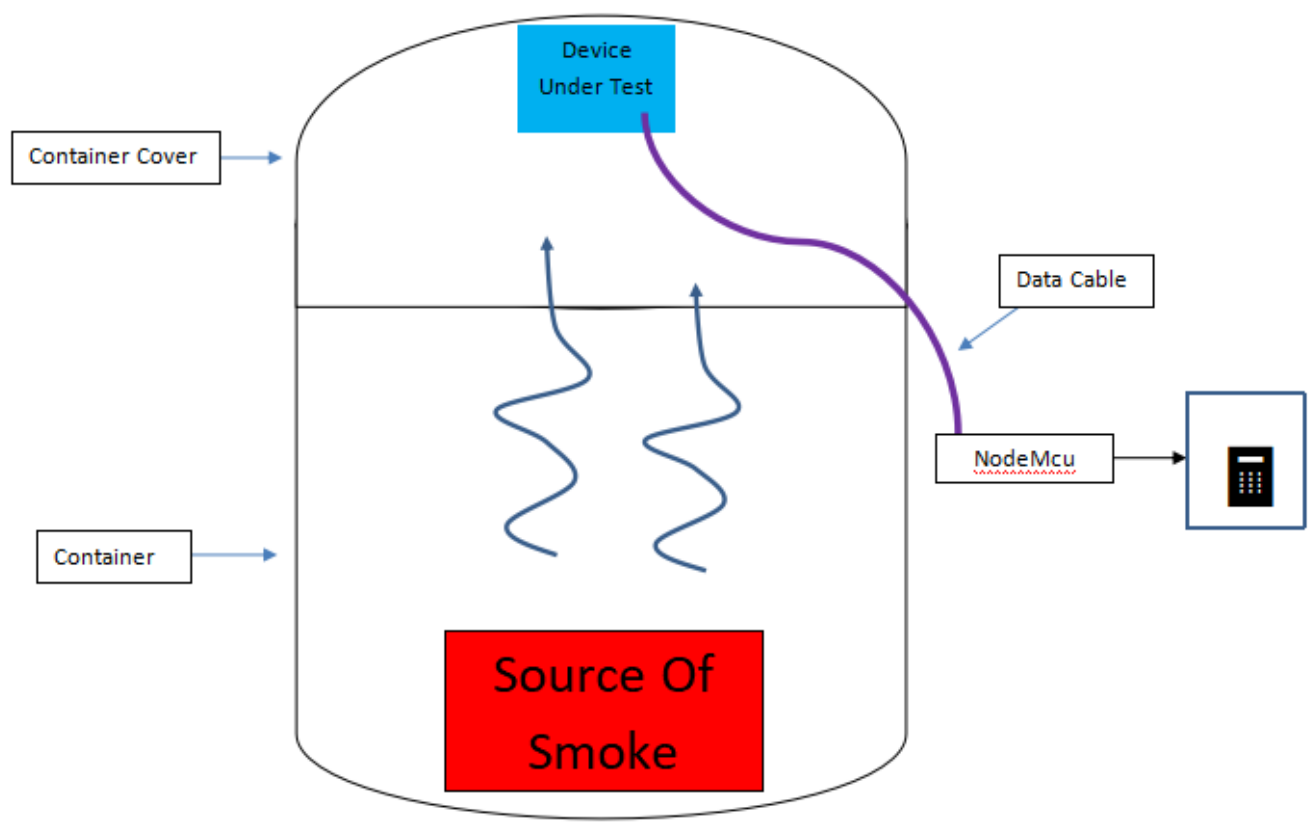

Figure 4. Monoxide CARbon Detection System Testing SCHEME

Testing Method:

1. The MQ-135 sensor and CO gas sensor are placed on the top of the container lid.

2. The MQ-135 sensor is connected to the Nodemcu to retrieve the data from the MQ-135 sensor measurement then send it to the internet and the PC. On a PC, data transmission uses serial communication.

3. Sources of smoke made of burned paper are then put into the container.

4. Then the container is closed and waited until the alarm on the $\mathrm{CO}$ gas sensor sounds.

5. Gas resulting from the combustion process will go up to the lid of the container. This gas is then measured for its $\mathrm{CO}$ concentration.

6. When the alarm sounds, the lid is opened, and the $\mathrm{CO}$ gas measurement results are observed on the commercial $\mathrm{CO}$ gas sensor.

7. The test result data is then stored and compared between the $\mathrm{CO}$ gas readings via the MQ-135 sensor and the commercial $\mathrm{CO}$ gas sensor. 
INTENSIF, Vol.5 No.1 February 2021

ISSN: 2580-409X (Print) / 2549-6824 (Online)

DOI: https://doi.org/10.29407/intensif.v5i1.14844

The test method used in this study originated from a literature study regarding the sensor's properties and characteristics and the adverse effects caused by exposure to carbon monoxide gas on the human body, which has been published in articles and journals related to the device to be made. In Figure 5 below, it can be seen that there is a connection between the MQ-135 sensor and the NodeMCU microcontroller.

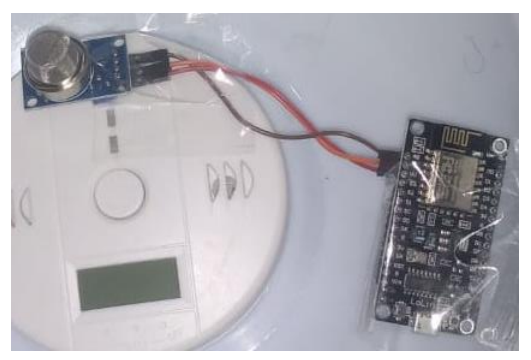

Figure 5. MQ135 AND NODEMCU SENSOR CONNECTION

The tests carried out are related to the function of each component as part of the system. A commercial CO Detector with the Kerui brand is used as a comparison tool, as shown in Figure 6 below.
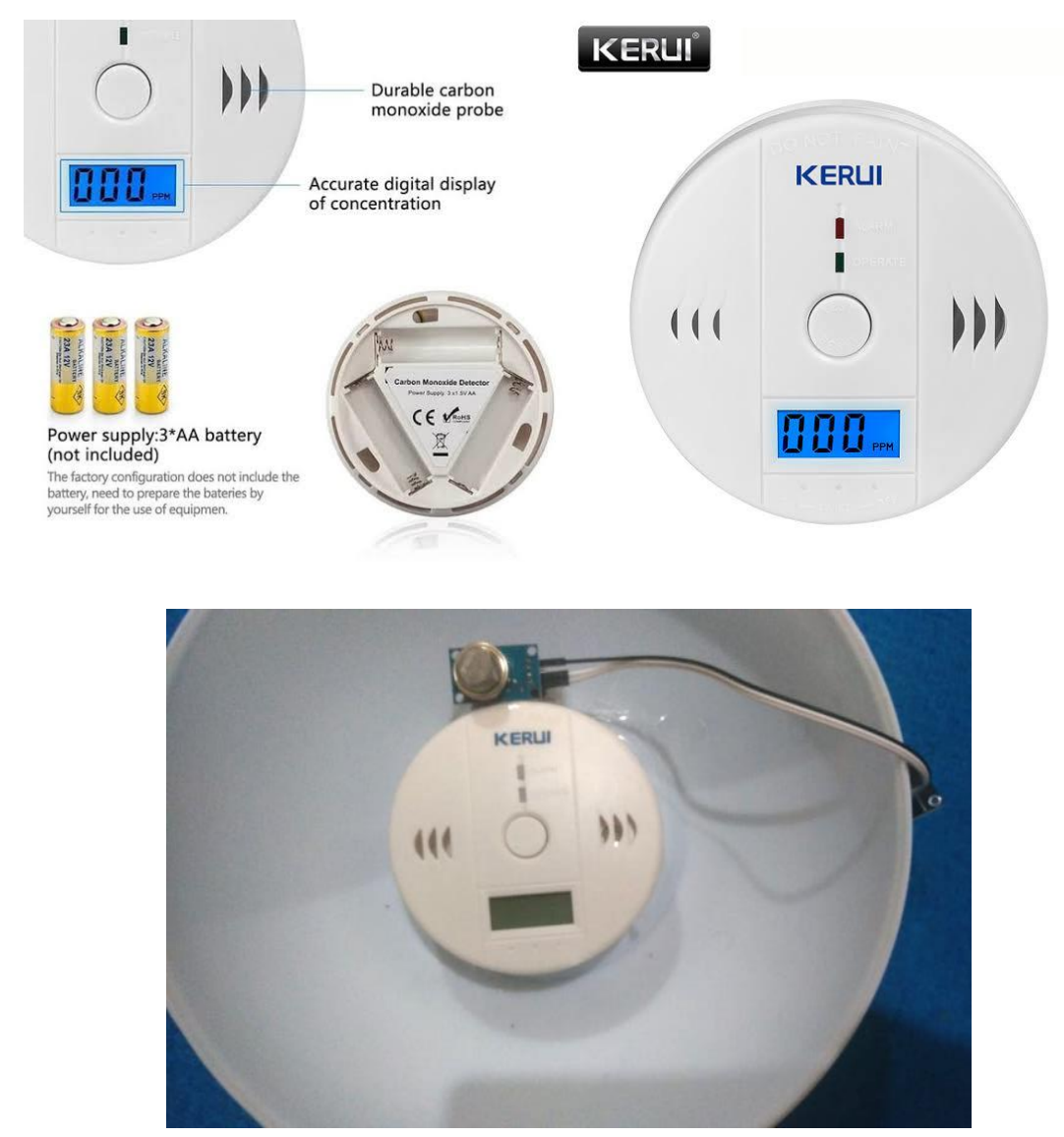

Figure 6. CERAmic Monoxide CARbOn Gas DeteCtor AND Iot DEVICES

128 INTENSIF: Jurnal Ilmiah Penelitian dan Penerapan Teknologi Sistem Informasi 
The testing process is carried out by giving gas containing carbon monoxide (CO) around the MQ135 sensor area. An example of the gas used in this study is a burnt containing carbon monoxide gas, then brought closer to the sensor area. So that the sensor can detect carbon monoxide gas $(\mathrm{CO})$ and program it on the nodeMCU board, matching it with the air quality level according to the value read by the sensor. The results of system function testing are shown in Table 2,

Table 2. SYSTEM FUNCTION TESTING

\begin{tabular}{|c|c|c|c|}
\hline Component & Condition & Function Testing Process & Result \\
\hline $\begin{array}{l}\text { Quality Air } \\
\text { sensor } \\
\text { (MQ135) }\end{array}$ & $\begin{array}{l}\text { The sensor is in a } \\
\text { stand-by position, } \\
\text { and the detector is } \\
\text { active. }\end{array}$ & $\begin{array}{l}\text { Provides a gas containing } \\
\text { carbon monoxide (CO) } \\
\text { around the MQ135 sensor }\end{array}$ & $\begin{array}{l}\text { The MQ135 sensor can } \\
\text { detect the presence of } \\
\text { carbon monoxide (CO) } \\
\text { gas. }\end{array}$ \\
\hline Thingspeak & $\begin{array}{l}\text { Thingspeak has a } \\
\text { section that can } \\
\text { record air quality } \\
\text { data read by the } \\
\text { MQ135 sensor. }\end{array}$ & $\begin{array}{l}\text { Test if the device can } \\
\text { record the sensor value in } \\
\text { the Thingspeak section }\end{array}$ & $\begin{array}{l}\text { Thingspeak receives } \\
\text { data from sensors and } \\
\text { displays it in graphical } \\
\text { form. }\end{array}$ \\
\hline NodeMCU & $\begin{array}{l}\text { The active detector } \\
\text { and } \\
\text { microcontroller are } \\
\text { connected to the } \\
\text { MQ135 sensor. }\end{array}$ & $\begin{array}{l}\text { The microcontroller will } \\
\text { process the analog input } \\
\text { obtained from the MQ135 } \\
\text { sensor. }\end{array}$ & $\begin{array}{l}\text { NodeMCU receives } \\
\text { signal input from the } \\
\text { sensor and processes it. }\end{array}$ \\
\hline Blynk & $\begin{array}{l}\text { The Blynk } \\
\text { application is pre- } \\
\text { installed on the } \\
\text { smartphone and is } \\
\text { active. }\end{array}$ & $\begin{array}{l}\text { Test the value sent from } \\
\text { the sensor so that the } \\
\text { device can pass it on to the } \\
\text { Blynk App }\end{array}$ & $\begin{array}{l}\text { The Blynk application } \\
\text { can receive notification } \\
\text { messages about air } \\
\text { quality levels. }\end{array}$ \\
\hline
\end{tabular}

The following image shows the results detected by the MQ135 sensor. On display, there is a point that indicates the value in real-time. In the test scenario, the tool is carried out by activating and placing it in a container filled with smoke. In the image below, a red arrow indicates that when smoke is introduced, in tests 1,2 , and 4 , which are shown in the following figure, the sensor detected carbon monoxide (CO) gas. But in test 3, it wasn't. The next process is to observe the results in the form of values that appear on the IoT Thingspeak platform. The recorded analog values come from the sensor and are forwarded to Thingspeak, and then the values are taken randomly with a specific period. The following are the data results obtained to find out the average analog value recorded by the sensor. 
INTENSIF, Vol.5 No.1 February 2021

ISSN: 2580-409X (Print) / 2549-6824 (Online)

DOI: https://doi.org/10.29407/intensif.v5i1.14844
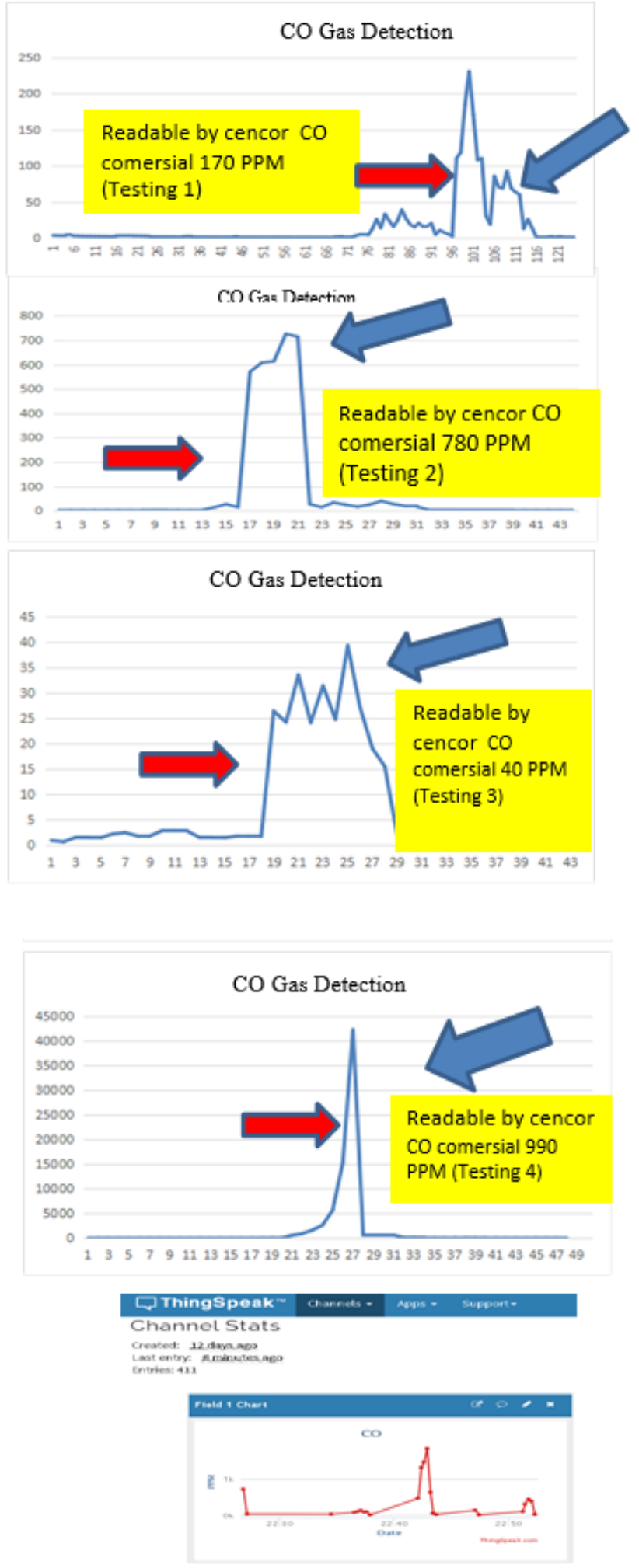

Figure 6. TESTING DEVICES AGAINST GAS CO 
The following image shows the appearance of Blynk apps that a smartphone accepts. A sensor in the range 0 can read the analog value to 1023 , represented by the sensor in a deal with 0 to 3 Volts.

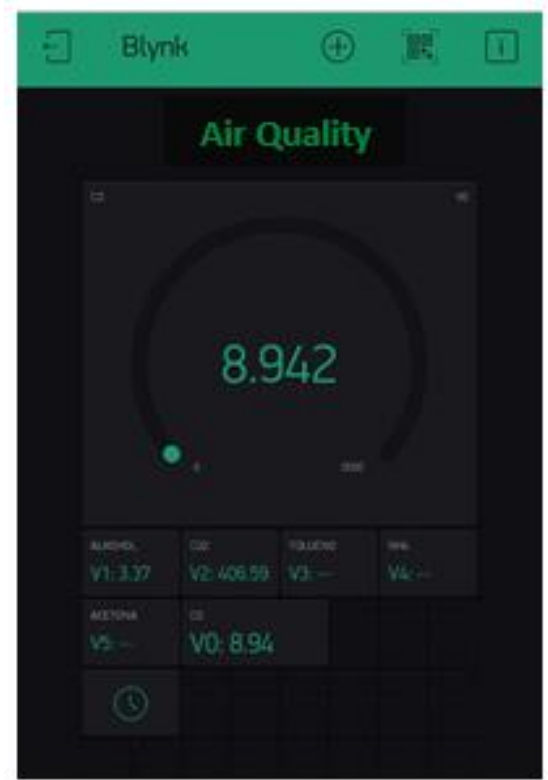

Figure 7. DISPLAYS ON THE BLYNK APPLICATION

\section{CONCLUSION}

Based on the results of the research conducted, researchers conclude that the prototype built is an air quality detector which utilizes a NodeMCU board microcontroller. Researchers can compare an air quality sensor with the MQ135 type connected to Blynk Apps and Thingspeak to commercial products where the device is made to detect carbon monoxide (CO) gas and has an added advantage to send real-time data over the internet. Then Blynk apps connected to the NodeMCU board and the MQ135 air quality sensor via a wifi module can send notifications to the user's smartphone about the room's detected air quality conditions. Furthermore, thingspeak performs a monitoring function and displays the monitoring results in the form of an air quality graphic recorded by the MQ135 air quality sensor in real-time, the air quality detector test was carried out in polluted air conditions for 30 minutes based on the test scenario. Moreover, the average air quality level data was obtained at an analog value of 495 and monitoring and notification systems to detect air quality contaminated with carbon monoxide (CO) gas can function as intended. Therefore, researchers can use them in spaces that require air quality monitoring, such as study rooms, to raise awareness about the importance of healthy air quality. 


\section{ACKNOWLEDGMENTS}

Acknowledgments to the Directorate of Research and Community Service, Directorate General of Research and Development Strengthening Ministry of Research, Technology, and Higher Education following Decree Number 8 / E1 / KPT / 2020, January 24, 2020, and Agreement / Contract Number 083 / SP2H / LT / DRPM / 2020, dated March 9, 2020; 042 / SP2H / LT- MONO / LL7 / 2020, dated March 17, 2020; 025.1 / LPPM UN PGRI Kd / A / III / 2020, dated March 24, 2020, which has provided financial support for this research.

\section{REFERENCES}

[1] L. Fitria, R. A. Wulandari, E. Hermawati, and D. Susanna, "Kualitas Udara Dalam Ruang Perpustakaan Universitas X Ditinjau Dari Kualitas Biologi, Fisik, Dan Kimiawi," Lingkungan, Dep. Kesehat. Masyarakat, Fak. Kesehat. Indones. Univ., vol. 12, no. 2, pp. 76-82, 2008.

[2] R. of I. Government, "Peraturan Pemerintah Republik Indonesia No 41 Tahun 1999," pp. $1-2,1999$.

[3] M. Hazsya, N. Nurjazuli, and H. L. Dangiran, "HUBUNGAN KONSENTRASI KARBON MONOKSIDA (CO) DAN FAKTOR-FAKTOR RESIKO DENGAN KONSENTRASI COHb DALAM DARAH PADA MASYARAKAT BERESIKO DI SEPANJANG JALAN SETIABUDI SEMARANG,” J. Kesehat. Masy., vol. 6, no. 6, pp. 241-250, 2018.

[4] A. S. Suparman and S. Yazid, "Purwarupa Sistem Pemantauan Kualitas Udara Secara Daring," Informatics Final Year Proj., vol. 1, no. 3, 2014.

[5] S. Jangid and S. Sharma, "An embedded system model for air quality monitoring," in 2016 3rd International Conference on Computing for Sustainable Global Development (INDIACom), 2016, pp. 3003-3008.

[6] Q. Yang, G. Zhou, W. Qin, B. Zhang, and P. Y. Chiang, "Air-kare: A Wi-Fi-based, multi-sensor, real-time indoor air quality monitor," in 2015 IEEE International Wireless Symposium (IWS 2015), 2015, pp. 1-4.

[7] J. M. S. Waworundeng and O. Lengkong, "Sistem Monitoring dan Notifikasi Kualitas Udara dalam Ruangan dengan Platform IoT," Cogito Smart J., vol. 4, no. 1, pp. 94-103, 2018.

[8] H. Anwari, E. S. Pramukantoro, and M. H. Hanafi, "Pengembangan Iot Middleware Berbasis Event-Based dengan Protokol Komunikasi CoAP, MQTT dan Websocket," J. Pengemb. Teknol. Inf. dan Ilmu Komput. e-ISSN, vol. 2548, p. 964X, 2017.

[9] J. Dutta, F. Gazi, S. Roy, and C. Chowdhury, "AirSense: Opportunistic crowd-sensing based air quality monitoring system for smart city," in 2016 IEEE SENSORS, 2016, pp. $1-3$.

[10] A. S. R. Sujatmoko, J. Waworundeng, and A. K. Wahyudi, "Rancang Bangun Detektor Asap Rokok Menggunakan SMS Gateway Untuk Asrama Crystal di Universitas Klabat," Proc. Konf. Nas. Sist. dan Inform., 2015.

[11] C. R. Candrasari and J. Mukono, "Hubungan Kualitas Udara dalam Ruang dengan Keluhan Penghuni Lembaga Pemasyarakatan Kelas IIA Kabupaten Sidoarjo," J. Kesehat. Lingkung., vol. 7, no. 1, pp. 21-25, 2013.

[12] F. Puspasari, I. Fahrurrozi, T. P. Satya, G. Setyawan, and M. R. Al Fauzan, 
"PROTOTIPE SISTEM KENDALI SUHU DAN KELEMBABAN KANDANG AYAM BROILER MELALUI BLYNK SERVER BERBASIS ANDROID," Wahana Fis., vol. 3, no. 2, pp. 143-147.

[13] F. H. Nainggolan, M. H. H. Ichsan, and G. E. Setyawan, "Implementasi Low Power pada Sensor Node dengan Protokol Komunikasi Zigbee," J. Pengemb. Teknol. Inf. dan Ilmu Komput. e-ISSN, vol. 2548, p. 964X, 2020.

[14] H. Supriyono, U. Bimantoro, and K. Harismah, "SISTEM PORTABLE MACHINE TO MACHINE UNTUK PEMANTAUAN KUALITAS UDARA DAN LINGKUNGAN (STUDI KASUS PADA KANDANG AYAM)," Proceeding of The URECOL, pp. 7083, 2019.

[15] R. Pressman and B. Maxim, Engenharia de Software-8a Edição. McGraw Hill Brasil, 2016.

[16] “ThingSpeak," The MathWorks, Inc., 2018. https://bit.ly/2JKng0Q.

[17] “Technical Data MQ135 - SNS," olimex, 2020. https://bit.ly/2xIeOh3.

[18] "NodeMCU," nodemcu, 2018. https://www.nodemcu.com/index_en.html (accessed Jul. 11, 2020).

[19] R. Amrutkar, S. Vikharankar, and L. Ahire, "Security: Smart Homes Using Internetof Things (IOT),” Int. Eng. Res. J. (IERJ), ISSN, pp. 1621-2395, 2016.

[20] MIT License, "Blynk," MIT License, 2017. http://docs.blynk.cc/\%0A. 